\title{
ARTICLES
}

\author{
Submitted 11.14.2019. Approved 11.30.2020
}

Evaluated through a double-blind review process. Guest Scientific Editor: Rosalia Lavarda

Original version | DOI: http://dx.doi.org/10.1590/So034-759020210605

\section{WORKING AT THE CROSSROADS OF STRUCTURATIONIST AND DISCURSIVE APPROACHES: A METHODOLOGICAL TOOL FOR PRACTICE-BASED STUDIES}

\author{
Trabalhando na intersecção entre as abordagens estruturalista e discursiva: Uma ferramenta \\ metodológica para estudos baseados na prática
}

Trabajando en la encrucijada de los enfoques estructuracionista y discursivo: Una herramienta metodológica para los estudios basados en la práctica

\author{
Marlei Pozzebon ${ }^{1,2}$ | marlei.pozzebon@hec.ca| ORCID 0000-0001-5380-908X \\ Natalia Aguilar Delgado ${ }^{1}$ | natalia.aguilar-delgado@hec.ca | ORCID 0000-0002-2561-1970

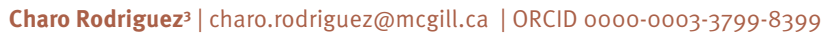 \\ ${ }^{1}$ HEC Montreal, International Business Department, Montreal, Quebec, Canada \\ ${ }^{2}$ Fundação Getulio Vargas, Escola de Administração de Empresas de São Paulo, São Paulo, Brazil \\ ${ }^{3}$ McGill University, Family Medicine Department, Montreal, Quebec, Canada
}

\section{ABSTRACT}

In this paper we propose a methodological tool that seeks to contribute to the empirical study of practices in organization studies. There is a need for innovating and improving analytical tactics for theorizing about practice, particularly for helping connect localized social interactions to broader contexts. We propose the "temporal bracketing of discourses" tool and provide a detailed example that empirically illustrates its application.

KEYWORDS | Practice-based studies, critical discourse analysis, structuration theory, temporal bracketing, texts-in-action.

\section{RESUMO}

Neste artigo, propomos uma ferramenta metodológica que busca contribuir para investigações empíricas da perspectiva da prática em estudos organizacionais. Existe a necessidade de inovar e aprimorar táticas analíticas para teorizar a prática, particularmente para ajudar a conectar interações sociais localizadas em contextos mais amplos. Este artigo propõe o "temporal bracketing" de discursos e inclui um exemplo detalhado que ilustra empiricamente a sua aplicação.

PALAVRAS-CHAVE I Perspectiva da prática, análise crítica do discurso, teoria da estruturação, temporal bracketing, textos em ação.

\section{RESUMEN}

En este artículo proponemos una herramienta metodológica que busca hacer una contribución al estudio empírico de prácticas en estudios organizacionales. Existe la necesidad de innovar y mejorar las tácticas analíticas para teorizar la práctica, en particular para ayudar a conectar las interacciones sociales localizadas con contextos más amplios. Proponemos la estrategia analítica temporal bracketing para los discursos e incluimos un ejemplo detallado que ilustra empíricamente su aplicación.

PALABRAS CLAVE I Perspectiva de la práctica, análisis crítico del discurso, teoría de estructuración, temporal bracketing, textos en acción. 


\section{INTRODUCTION}

The "practice-turn" has received a great deal of attention in organization studies and management literature over the last decade, particularly in fields like strategy (Jarzabkowski, 2008; Lavarda, Canet-Giner, \& Peris-Bonet, 2010; Whittington, 2006), knowledge management (Orlikowski, 2000) and information systems (Novak, Brooks, Gadd, Anders, \& Lorenzi, 2012), to cite a few. Practices in this tradition refer to "shared routines of behavior, including traditions, norms and procedures for thinking, acting and using 'things”' (Whittington, 2006, p. 619), which are recreated in what people do and say in situated interactions. Its focus on social life as ongoing production that emerges through people's recurrent actions has brought to light a much-needed shift towards agentic approaches to our field (Feldman \& Orlikowski, 2011). An increasing number of papers, special issues and books that espouse practice theories have been published in recent years, serving to consolidate the position and contribution - both conceptual and empirical - of practice-based studies as a strongly emergent research perspective (Feldman \& Orlikowski, 2011).

Conducting practice-based studies, however, is not without its difficulties, precisely because of the epistemological and methodological challenges they pose. Practice theories constitute a broad and complex intellectual landscape (Feldman \& Orlikowski, 2011). In terms of theoretical foundations, practice-oriented researchers draw on a number of sociological theorists, including Giddens (1984), Bourdieu (1990), Foucault (1980), and Schatzki (1996). Having "contributed to the questioning of the systematic and deterministic approaches that dominated American sociology until the end of the 1970s" (Denis, Langley, \& Rouleau, 2007, p. 196), and by proposing alternatives for overcoming classical dichotomist thinking, such as agency-structure, meaning-cause, relativism-objectivism, atomism-holism, autonomy-tradition, and micro-macro (Pozzebon, 2004), the theoretical stances proposed by such theorists are often complex and difficult to mobilize empirically. Organization theories that focus on fixed entities and on static box-and-arrow representations entail more instrumental and less ambiguous analytical tools than non-dichotomist social theories, which embrace emerging and never-fixed entities in ongoing, dynamic and always provisional relationships (Feldman \& Orlikowski, 2011). Another major challenge of theorizing practice lies in the connections between the "here-and-now" of the situated interactions and the

"elsewhere-and-then" of broader contexts (Nicolini, 2009). Put simply, the theoretical viewpoints borrowed by practice theorists are difficult to apply empirically.

Two theoretical lenses seem to have had a huge influence on the development of the practice-turn: structuration theory (Jarzabkowski, Balogun, \& Seidl, 2007; Whittington, 2006) and the organizational discursive school, particularly critical discourse analysis (Hardy, 2001; Phillips \& Oswick, 2012). Structuration theory has become so prominent in organizational studies because it tries to overcome the duality of structure and agency, and takes time and space into account seriously, although often the researchers using this perspective pay more attention to individual, situated activities, and less to the broad political context wherein those actions take place (Seidl \& Whittington, 2014; Whittington, 2010). Critical discourse analysis, which is considered one of the most "context-sensitive" discursive approaches (Grant, Hardy, Oswick, \& Putnam, 2004), is useful for explaining the connections between texts (micro) and broad political contexts (macro). It has been pointed out, however, that time is often a neglected dimension in these studies (Heracleous, 2013; Leitch \& Palmer, 2010).

In our study, we aim to provide an alternative tool for empirical work on practice-based studies by enriching the crossroads between structuration theory and critical discourse analysis. This article makes two main contributions. First, we take a step further in the effort to combine structuration theory and critical discourse analysis as a rich 
theoretical and methodological avenue for practice-based studies as we seek to understand everyday interactions without losing their connection to broader macro-influences, i.e., political, cultural, societal and others. We respond to calls for a better understanding of the links between organizational discourses, agents' actions, and change outcomes over time by focusing not just on the points of convergence among the theories (e.g., Heracleous, 2013; Heracleous \& Barrett, 2001), but mainly on the potential complementarity of these approaches vis-à-vis their mobilization in empirical works. Second, we present a detailed step-by-step methodological tool by which the cross-fertilization between these traditions can take place. We describe and illustrate temporal bracketing discourses as a methodological technique that aims to help researchers establish a connection between localized interactions and broader contexts, not only in "zooming-in and out" - mobilizing Nicolini’s (2009) metaphor but also "zooming-over-time".

\section{LITERATURE BACKGROUND}

\section{Structuration theory and its "sensitizing devices" for analyzing social practices}

Since the 1980 s, structuration theory has been seen as a promising avenue for resolving the longstanding debate over the relationship between structure and agency, a challenge not confined to organization theory but related to all social theory (Cohen, 1989). It is not our purpose in this section to propose a complete overview of Giddens' work, as a number of comprehensive and authoritative writings on the topic are available (e.g., Cohen, 1989; Held \& Thompson, 1989). Our focus is on revisiting the analytical avenues proposed by structuration theory for understanding the organizational and societal practices that are promising for improving empirical work on the practice-turn.

Previous work has looked at how structuration theory has been empirically employed in the context of information technology research (Pozzebon and Pinsonneault, 2005), and of organizational discourse (Heracleous, 2013). Following Giddens' application of structuration theory, those works suggest using sensitizing devices in a selective way in empirical work rather than as detailed guidelines for research procedure (Giddens, 1989, p. 294). In the same vein, we build on two key concepts of structuration theory which we use as sensitizing devices: duality of structure and time/space.

The duality of structure concept is at the core of structuration theory and emerges as an important device for both planning an empirical investigation and interpreting its results. Giddens departs from the conceptualization of structure as having some given or visible form. While structure is what gives form and shape to social life, it is not itself that form and shape. Structure is not always tangible but rather exists as memory traces in our minds and is being continuously recreated by human actions, reactions, voices, and silent compliances. Similarly, the author departs from the idea of agency as something "contained" within the individual. He does not refer to people's intentions in doing things, but more to the flow or pattern of people's actions (Giddens \& Pierson, 1998), which can either follow a given course or trace a different path. Taken together, these two notions help us understand the seminal concept of "duality of structure" (overly referred to but often misunderstood) that provides a richer understanding of social encounters. Structure is embedded in practice, or in a series of practices, in which it is recursively implicated (Giddens, 1976, 1984). 
In addition to the agency-structure duality, the notion of time/space is also central to structuration theory and is a key feature in understanding the properties of social systems: how people conceptualize time and space, and how they manage to organize themselves across time and space (Giddens \& Pierson, 1998). Giddens (1989) stresses the importance of studying the contextualities of institutionalized patterns of interactions across time and space, which are viewed as inherent in the investigation of social reproduction. Giddens argues that all social research necessarily has cultural, ethnographic or anthropological dimensions which are, nevertheless, often neglected in social studies. However, these key elements of structuration theory remain underutilized, more particularly the interpenetration of temporality pertaining to practices, individuals, and institutions (Heracleous, 2013).

Recent examples of the use of structuration theory's concepts in practice-based studies can be found in the strategy-as-practice stream (Jarzabkowski, 2008), where the influence of Giddens' ideas may be recognized in seminal works referenced in the area (Seidl \& Whittington, 2014). Jarzabkowski(2008) suggests that the link between the micro-level (strategizing activities) and the macro-level (wider society) is better understood by focusing on "management practices-in-use as the primary unit of analysis" (Jarzabkowski, 2004, p. 551). However, strategyas-practice scholars, whether or not inspired by structurationism, have tended to neglect social structural context (Whittington, 2010), leading to acritical and apolitical accounts (Carter, Clegg, \& Kornberger, 2008).

Similarly, Seidl and Whittington (2014) call for further practice research that effectively links "local" strategizing activity with "larger" social phenomena in an effort to overcome the tendency of "micro-isolationism, whereby a local empirical instance is interpreted wholly in terms of what is evidently present, cut off from the larger phenomena that make it possible" (p. 1408). An opportunity arises for practice researchers to enlarge their understanding of the larger social structures because the practice perspective bridges the gap between micro and macro-levels of analysis.

\section{Critical discourse analysis and its potential for connecting situated texts-in-action and broader contexts}

Within the broad discursive school, we have witnessed a persistent and increasing rise in the attention given to critical discourse analysis (Lacerda \& Brulon, 2013). Critical discourse analysis has a long history in socio-linguistics (Titscher, Meyer, Wodak, \& Vetter, 2000) and has begun to hold sway in organization studies over the last three decades (Grant, Keenoy, \& Oswick, 2001). Sharing with other discursive approaches that consider language not only as a tool for description and communication, but primarily as a means for constructing social reality (Kuhn \& Putnam, 2014), critical discourse analysis is characterized on the one hand by its emphasis on power relations, and on the other by its sensitivity to context (Grant et al., 2004; Phillips \& Hardy, 2002).

Being intertextual in nature, critical discourse analysis allows for identification of key ideas embedded in people's interpretive frames, and explains how these ideas go on to shape and influence people's actions and decisions. It helps throw light on the nature of power relations and their influence on organizational processes, and is particularly effective for highlighting multiple voices and perspectives, thereby helping to demystify assumptions that are taken for granted and revealing their consequences in terms of sustained inequalities of power (Grant et al., 2001, 2004; Phillips \& Hardy, 2002). Critical discourse analysis is powerful in interweaving multiple levels of analysis where discourse is understood by its embeddedness within sociocultural practices (Chouliaraki \& Fairclough, 2010; Fairclough, 1992, 1995; Fairclough \& Wodak, 1997). 
Fairclough sees critical discourse analysis as a "mode of critical inquiry where theory and methodology are inherently linked to one another" (Chouliaraki \& Fairclough, 2010, p. 1215). Fairclough's three-dimensional framework examines how discourse is constitutive of the social world by its analysis on three levels: the examination of language in use (the text dimension); identification of processes of textual production and consumption (the discursive practice dimension); and consideration of the institutional factors surrounding the event and how they shape discourse (the social practice dimension) (Thompson, 2004). These three levels of analysis are explained in more detail in the section in which we present our methodological approach.

Even if critical discourse analysts seek to establish a connection between micro-discursive activities and broader contexts, the major criticism of this body of literature is that it de-emphasizes the role of time (Heracleous, 2013; Leitch \& Palmer, 2010). This is why we claim that it is more useful to combine the empirical sensitizing devices of structurationist and discursive theoretical repertoires than to mobilize them separately. This we show in more detail in the next section.

\section{Bridging the gap between structuration theory and critical discourse analysis}

Most of the time structuration theory and critical discourse analysis have been applied separately (Balogun, Jarzabkowski, \& Vaara, 2011; Jarzabkowski, 2008), but some authors have been trying to combine them. Although these two viewpoints espouse different ontologies, they occupy what authors like Gioia and Pitre (1990) term 'transition zones', i.e., zones where each theoretical stream can tap into different but complementary facets of organizational phenomena, thus creating a dialogue. Two exemplary illustrations of this effort are the Montreal School of organizational communication (Spee \& Jarzabkowski, 2011; Taylor, Cooren, Giroux, \& Robichaud, 1996) and the work of Heracleous and colleagues on organizational discourse (Heracleous, 2013; Heracleous \& Barret, 2001).

We recognize from previous applications at least two major points of convergence and one important zone of complementarity. First, both encompass robust process logics for understanding social phenomena. Structure is embedded in practice, or in a series of praxis, in which it is recursively implicated over time and in historically situated spaces (Giddens, 1984). Although people's actions are central to most structurationist analysis, the concept of discourse has huge resonance in Giddens' work, where language is seen not merely as a functional tool, but as constitutive of social life, playing the role of a medium of social interactions (Heracleous, 2013). Second, both structurationist and discursive approaches understand that context is central for understanding social practices. Giddens (1984) argues that social studies often neglect the influence of broad political and cultural contexts, contending that time and space are compelling elements for a full understanding of context. However, as we could identify in previous analyses of practice-based organization studies, even those influenced by structuration theory, often stop their analysis and interpretation at the meso - organizational - level. This tendency is illustrated by numerous empirical works (e.g., Feldman, 2004; Kouamé \& Langley, 2018). Conversely, discursive approaches, particularly those colored by critical thinking, pay attention to particular contexts, but direct their foremost interest to the broad social and political realms that help explain the production of the local (Grant et al., 2004).

In this paper we explore a complementarity for bringing discursive approaches and structurationist studies closer together: recalling the importance of not limiting the duality of agency/structure to localized sayings and doings (individual) or emerging patterns as routines, discourses, scripts, and genres (organizational). Instead, in expanding the notion of context and anchoring it in time and space, practice scholars should be in a better position 
to reconnect situated local doings and sayings to more macro-contexts - broad political, social and cultural shedding light, in turn, on the conditions necessary for reproducing or transforming organizational practices over time. Refining this idea, the value of bridging the gap between critical discourse analysis and structuration theory lies in uncovering organizational practices that unfold over time through a better understanding of how discourses situated in time and space influence and are influenced by social structures. The literature has already pointed out the empirical challenge of going beyond observation of the temporal location of communicative actions within the context of a conversation, event, or text, and the need to try to bridge those elements with institutional features (Heracleous, 2013). We argue that with this dual perspective, we are able to appreciate how power relations are sustained, reproduced and resisted through discourses enacted in texts that are produced in everyday contexts when anchored in time and space. Furthermore, blending the duality of agency and structure with critical discourse within an actionable framework enables us to better understand another relevant, yet often neglected interplay: texts and actions, more precisely, texts-in-action. By recognizing and analyzing a range of texts as they are being produced, and by identifying the discursive practices enacted by those texts, we can increase our understanding of how social practices are constituted in organizational settings, and result in intended and unintended consequences. In what follows, we present our proposal for applying this dual lens in empirical research.

\section{APPLYING TEMPORAL BRACKETING TO SPEECHES: ZOOMING-IN, -OUT AND -OVER- TIME}

In proposing an analytical approach that blends a structurationist view with critical discourse analysis, we combine temporal bracketing strategy, as defined by Langley (1999), and critical discourse analytical techniques, as proposed by Fairclough (1995) - see Figure 1.

\section{Figure 1. Temporal bracketing and Fairclough's three-dimensional framework}

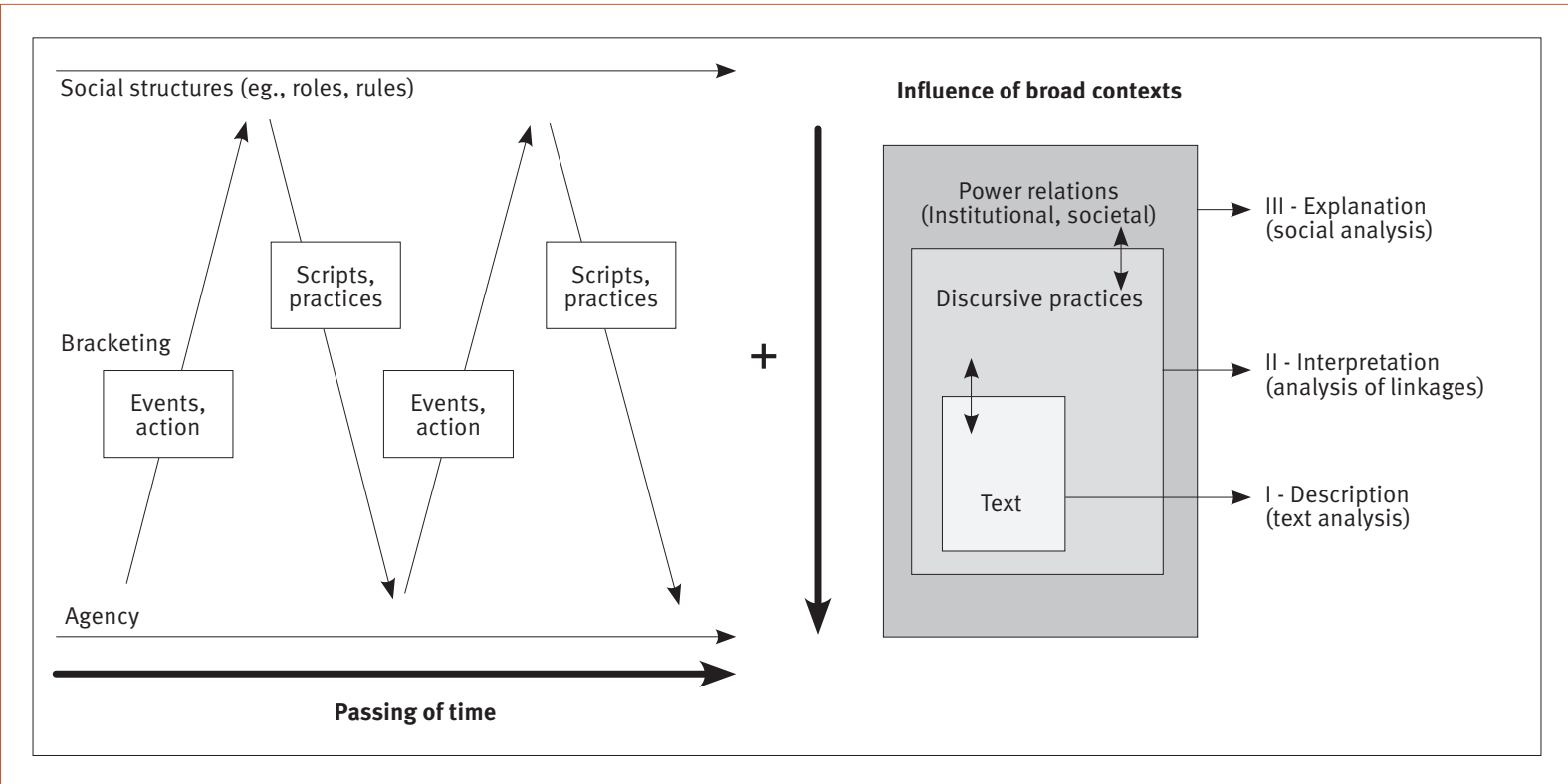


Temporally bracketing data is not a new methodological strategy in organization studies (Barley, 1986; Howard-Grenville, 2005). Temporal bracketing has traditionally meant breaking down data into successive periods to examine how actions in one period lead to changes in the social structures that will affect action in subsequent periods. This tool has been recognized as a classic - although not exclusive - example of a perspective that embraces a processual and recursive logic that is intrinsic to the duality of agency/structure. Because the interplay between structures and action is difficult to capture, it is easier to analyze them sequentially by temporally bracketing them (Langley, 1999). One classic example of temporal bracketing in organization studies is Barley's (1986) sequential model of structuring, where the notion of scripts - outlines of recurrent patterns of interactions that help define actors' roles - serves as a link between the action and institutional realms.

The second research technique is based on the work of Fairclough (1995). Our choice was driven by the synergy of two elements: the view that Fairclough's framework is among the most adopted by organizational and management scholars (e.g., Grant et al., 2001, 2004; Phillips \& Hardy, 2002; Titscher et al., 2000; Wood \& Kroger, 2000; Rodriguez \& Pozzebon, 2010) and identification of an actionable step-by-step methodological strategy based on his work (e.g., Thompson, 2004). Fairclough's framework suggests three phases of analysis: description, interpretation and explanation. Our methodological approach - temporal bracketing of discourses - enriches these three elements from the frame developed by Fairclough, precisely by emphasizing the temporal nature of organizational events under scrutiny, including an intermediary and imbricated step: bracketing (Figure 2). Here we represent the recursive cycles of texts-in-action and discursive practices that reinforce certain patterns of action.

\section{Figure 2. Temporal bracketing of discourses}

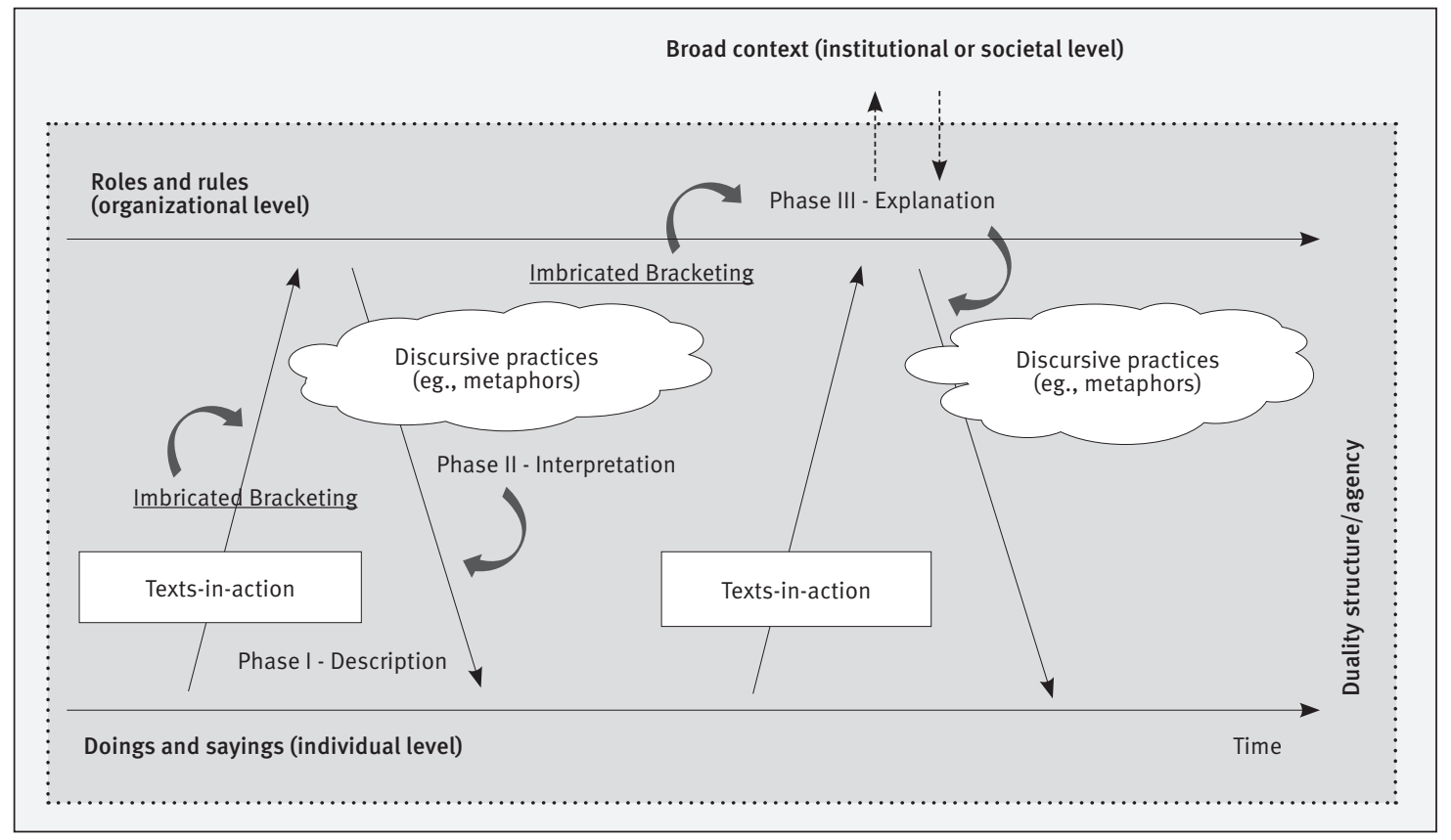


Phase I consists in the description of each piece or fragment of text. In this text analysis process, the spoken and written materials produced and consumed by the actors are described and put into context. The researcher collects texts-in-action, which means that $\mathrm{s} /$ he accompanies the moment when the texts are produced by the actors, being immersed in the context of text production and consumption. In Phase II, emphasis is placed on identifying and interpreting patterns in the production and consumption of texts, the so-called discursive practices. This phase can involve a variety of tactics, as exemplified in Cassell and Bishop (2018), including the use of metaphors (the way people express their experience and understanding of one thing in terms of another), templates (defining and organizing themes), stories (sequence of actions and experiences constructed around resonant plots and characters), representations (the fact of expressing or denoting by means of symbols), images (a spoken or written description) and concepts borrowed from other theoretical viewpoints or emerging from the researcher's interpretation. In particular, metaphor was used in this work as one of the interpretive devices that researchers might mobilize (see Cornelissen, Oswick, Christensen, \& Phillips, 2008; Heracleous \& Jacobs, 2008 for more).

Data emerging from Phases I and II are bracketed in order to examine how texts-in-action cumulatively contribute to the structuring of organizational roles and rules by reinforcing or transforming existing organizational structures or creating new ones. In Phase III, the researcher tries to develop an explanation generated by the connection of the interpretations unfolding over time and space, i.e., the links between the sustained observations of ongoing interactions, and the analysis of discourses within the overall context. The researcher puts into context the conditions and power relations that enable and constrain the production and interpretation of texts. In this sense, the analysis should take into account not only the emergence of discursive practice, but the researchers' observations over time (proximal context) and their consideration of broader contexts (e.g., organizational, institutional, regional). It is important to note that the bracketing steps are imbricated between Phases I, II and III.

Some fieldwork practices facilitate the application of the temporally bracketing discourse tool. The first is that data collection of texts-in-action is ideal for enabling researchers to become much more aware of the conditions - situational, institutional and societal - that help explain the meanings of the texts produced and consumed. Relying solely on texts collected a posteriori (often through interview or archival data), although valuable, provides a partial picture of the process at hand. Gestures, silences and absent voices, as well as contradictions between doing and talking, all convey a great deal about organizational processes that are not captured when we rely only on texts gathered from interviews or documents. We therefore strongly support the use of data emerging from ethnography - participant and non-participant observation. The use of ethnographical techniques in management research is encouraged by an increasing number of scholars (Berthod, Grothe-Hammer, \& Sydow, 2017; Jarzabkowski, Bednarek, \& Lê, 2014), because the meanings of texts are conditioned by their context and the perceptions of the agents producing or consuming those texts (Heracleous, 2006).

Second, our view of the use of temporal bracketing is closer to structurationist recursive logic, thus privileging a fine-grained treatment of empirical material (Pozzebon \& Pinsonneault, 2005). Fine-grained bracketing purposively breaks down events into the effects of action on structures, on the one hand, and the effects of institutional constraints on action on the other, over a thin continuum of time. Temporal bracketing strategy in its fine-grained form requires a kind of data density, i.e., the researcher needs to be able to draw close to the empirical data and collect it intensively over time in order to carefully examine how specific actions lead to contextual changes which will again affect action, and so on. 


\section{An empirical illustration: the CONFIG Project}

The empirical illustration reported in this paper is based on a longitudinal in-depth case study whose aim was to understand the processes whereby an international consulting-firm (CONSULT) and its clients from a client-firm (FIRM) undertook to implement a configurable technology in a project called CONFIG. CONSULT is the fictitious name of a Canadian consulting agency that sells and implements configurable packages. FIRM is the fictitious name of a Canadian aerospace firm that decided to implement one of the configurable solutions offered by CONSULT. CONFIG is the fictitious name of the project involving the implementation of configurable technology by CONSULT at FIRM. Configurable technologies are a massive trend in the technology industry and refer to those technologies that are highly parameterizable, being built up from a range of components to meet the very specific requirements of a particular organization.

We call this an "empirical illustration" because the original case study was reported elsewhere and here it is applied merely as an illustration of the application of the methodological approach. The fieldwork was characterized as intensive and quasi-ethnographical (Murtagh, 2007). The case study mobilized intense fieldwork techniques (participation in meetings and sustained on-site observation in the organization - FIRM - receiving the new technology), documentary analysis (including all electronic messages exchanged between the consultants and clients), and 16 non-structured interviews, each 1-2 hours long. One of the researchers had the opportunity to be allocated a desk in FIRM where they were able to stay an entire day, once a week for six months, which afforded us the opportunity to directly observe the unfolding of events over time without many restrictions in terms of access. We had full access to observe formal meetings, to analyze project documents and emails exchanged, to make regular visits, to observe and to conduct interviews in both the client-firm and the consulting-firm. At CONSULT, the project team included nine people, of whom we interviewed the two consultants who interacted intensively with the client's personnel: the project director, Ella, and the project manager, Liz (all names used here are fictitious). We also interviewed the project manager from the client-firm, Nils.

With full appreciation of the context, the focus of the investigation was the interactions between the main actors engaged in negotiating their roles when implementing the configurable technology over time. CONFIG's actors decided to organize the technology implementation process into two consecutive periods: Period 1, involving the preliminary conversations and meetings; and Period 2, which included analysis and parameterization. We respected these periods when temporally bracketing our data, because not only were they meaningful to the practitioners, but they also presented critical turning points in the relationships that had been established between the actors.

We started to analyze data in parallel to data collection, using the proposed methodological tool: Phases I, II and III with an imbricated step, bracketing. Figure 3 schematically illustrates the temporal bracketing of some of the texts-in-action and the progressive emergence of some discursive practices of authoritative content.

\section{Period 1 - Initial negotiations between CONSULT and FIRM members}

Phase I-Description: Because we observed the initial negotiations of the project's roles and rules, our main texts in this phase were fieldwork notes and the verbatim transcription of interviews. From the very beginning, the process by which clients and consultants jointly influenced decisions about how the configurable technology would work was constructed on the basis of well-defined and mutually agreed upon roles, as we could observe during formal meetings and informal conversations. Based on their technical expertise, consultants from CONSULT had control over the project and were formally responsible for all technical aspects of the configuration. Consultants 
negotiated their role as experts, while clients from FIRM were trained to use, not to configure, the system. Based on their knowledge of local requirements, the clients would provide the information required by the consultants and would make configurational choices in light of their grasp of the range of possibilities offered by the consultants. In this view, clients assume the role of information providers, with consultants presenting this division of roles as something natural and appropriate.

Our goal is to propose alternatives that correspond to their needs (...). The client tells us exactly (...) what their departments are, how they work... We look into our system and see... what we can do in our system.... (Liz, CONSULT)

Acceptance, and the verbal expression thereof, that clients need only "tell exactly what their departments are" legitimizes their role as information providers, and puts forward a belief that organizational needs are easily transferred verbally. Similarly, accepting that the consultants will "look into their system and see what they can do", legitimizes their role as experts and the belief that their methods actually lead to sound definitions of organizational requirements and appropriate solutions.

\section{Figure 3. Temporally bracketing discourses applied to the empirical illustration}

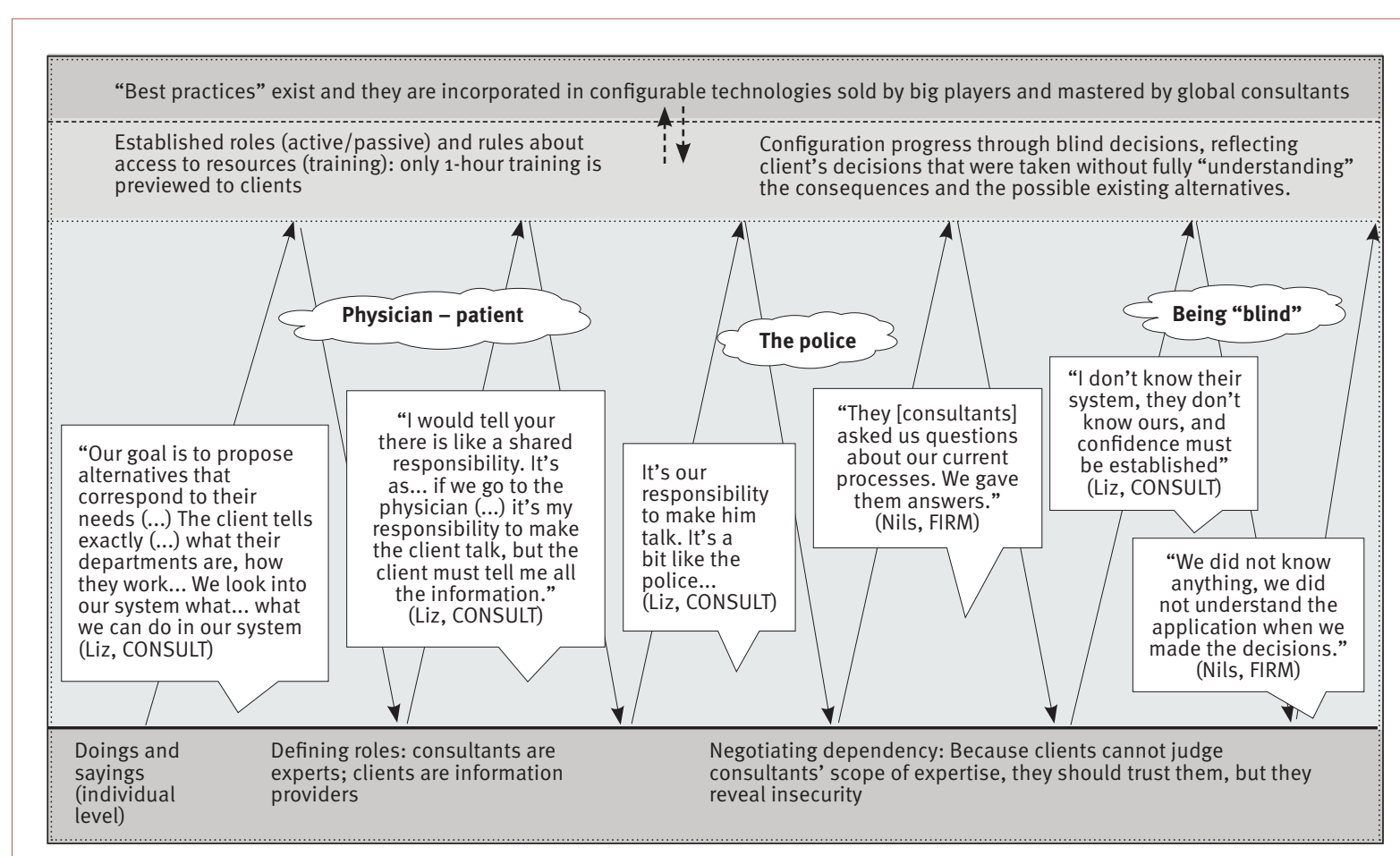

Phase II - Interpretation: Discursive practices progressively emerged in the form of metaphors, images and representations that were mobilized for legitimizing this natural and "appropriate" division of roles. This is illustrated in exemplary fashion in the emergence of the "physician-patient" metaphor. By observing the exchanges between the main actors during Period 1, we grasped that a "physician-patient" relationship framed and legitimized the definition of their roles, establishing an initial balance of power - who the expert is - which 
strongly influenced the negotiation that would follow. These discursive practices directly affected the rules established concerning the allocation of resources: if clients are merely information providers, they do not need to be trained with regard to the new technology because the consultants will take care of the configuration for them. By not only analyzing the texts, but also observing the actors at the moment of the production of those texts, we could observe fragility, insecurity and a certain process of "infantilization" in the gestures and responses of the client when interacting with the consultant in the first important meeting.

Phase III - Explanation: The authoritative effect of the physician-patient metaphor helps explain the construction of a dependency path. Clear evidence that a dependency path was being constructed was the mutually agreed upon absence of training for client members. Actually, only a single day of training was planned before the project launch, a brief orientation that provided a general and limited view of the functionalities of the package. These initial decisions served to establish an arena with a number of characteristics that, although not immutable, contributed to shaping certain consequences. The clients' lack of training can be understood as a direct and logical consequence of an initial and mutually agreed power/expertise balance, an initial consequence of the pattern being traced - a dependency path. Limiting training to such a short period - one day - would have a strong effect on the nature of the clients' interventions and their participation as project team members. Here, we mobilize the understanding that "paths of dependency" between client firms and consultants should be located in the broad context, at the societal or institutional level.

Imbricated bracketing: Description and interpretation were bracketed with and within the explanation. The recursive bracketing of texts-in-action and analysis of the progressive emergence of discursive practices - in our case, in the form of metaphors and images - shaped subsequent texts-in-action. This helped us grasp more clearly the effect of temporality on the structuring of roles and rules over time.

Provisional insights from temporally bracketing discourses from Period 1: The previous explanation was enabled by two strong and parallel interdependent institutional, macro-processes: the building of the idea of best practices and the intense merger/acquisitions/outsourcing characterizing the period beginning in 2000 and continuing until today. Particularly in the information and communication technology (ICT) industry, we have witnessed the emergence and permanence for decades of an omnipresent discourse (with a capital "D") about the existence of "best practices", leading thousands of firms worldwide to buy consultants' "solutions" as the only avenue to fixing informational problems. This concept of best practices was seen as an actionable tool to facilitate another powerful phenomenon: the merger/acquisition of small and medium-sized firms by big corporations and the collateral outsourcing of numerous organizational activities. When Ella, Liz and Nils started their "negotiations", FIRM had just been acquired by a bigger firm, and CONSULT was considered one of the big players in ICT consulting, having best practices as their motto.

\section{Period 2 - Configurational activities}

Phase I-Description: After the initial negotiation of roles, core configurational activities were carried out. Clients were invited to participate in numerous meetings, phone conversations and intensive e-mail exchanges, some of which we were able to observe on-site. In all these situations, a common dynamic emerged: consultants asked questions; clients answered (information providers); based on the information provided, consultants offered different configuration possibilities (experts); and clients selected one. For example, during the second important formal meeting we observed, the information exchange was led by consultants who were driven by the premise 
that, with the help of their methodologies and implementation agenda, they would be able to extract "accurate" information about user requirements and specific particularities. However, in order to make the user responsible for providing accurate information, the metaphor of "physician" was again mobilized:

Er, yes, but I would tell you there is like a shared responsibility. It's as... if we go to the physician, and we say that we have a little headache, but eventually we have a huge migraine... the doctor won't be able to help us properly. Actually, it... yes, it’s my responsibility to make the client talk, but the client must give me all the information. (Liz, CONSULT)

The configuration process is based on power inequality (consultants lead the project), since only consultants have expertise in the configurable tool. Based on their knowledge of the package's features and parameters, and on the information provided by clients, consultants "offer" different configuration possibilities. Clients, in turn, are consultant-dependent: they cannot "read" the package's possibilities, so they must rely on the consultants' suggestions.

Phase II - Interpretation: The inequality previously described is clearly reinforced by an additional type of metaphor - "police"- articulated by consultants when they describe their relationship with clients. During the two formal meetings that we observed, we saw that clients made important configuration decisions, but were hugely uncertain. We could observe the clients' frequent hesitation and uncomprehending facial expressions, something that could not be easily grasped in interviews. In the second formal meeting we observed, we noted that on more than one occasion Liz asked Nils an important question, but he seemed not to clearly understand what Liz was talking about. They tried to explain their viewpoints to each other without success. At a certain point, Nils seemed to be embarrassed by the situation and made a decision without fully understanding the consequences of his choices and without being aware of their appropriateness vis-à-vis other possible choices. Observation of interactions in this case highlighted the advantage of going beyond recorded interviews, as we were able to witness a type of negotiation which we characterized as a blind decision-making process.

We knew nothing, we didn't understand the application when we made decisions. (Nils, FIRM).

The image of "being blind" was also grasped by observation of texts-in-action. Consultants also work with uncertainty. Therefore, they mobilize particular discursive strategies to legitimize their role as experts and, at the same time, to reduce their responsibility if things go wrong. The main tactic depicted is to assign increasing responsibility to the client in his/her role as information provider, so that offering optimal choices depends on getting the right information, which the client is expected to provide.

If the client... doesn't give me the information, then ... even if I wanted to give him a more interesting option I couldn't because really I got to the end of my questions and eventually he didn't come up with ant interesting points ... Then... so the client is responsible for the information he gives. (Liz, CONSULT)

Phase III - Explanation: The dependence dynamic being established over time (whose foundations existed from the very first meeting between client and consultant) might be only understood if we connect with the broad context of the ICT industry and consider the prevalence of outsourcing/mergers that is characteristic of the 21st century. Analysis and interpretation of these data, which stopped at the "meso" - organizational - level, might find an explanation for the dependency being built into the culture of the firms involved, or in the individual 
personalities of the key actors. But an understanding of the macro-climate of the ICT industry and the pervasive domination of best practice theories probably explains a lot about the construction of dependency paths.

Imbricated bracketing: What is relevant here is that we could not have achieved this degree of nuanced understanding based solely on interviews. Neither could that degree have been achieved without temporally bracketing the discursive practices. The dynamics of one person asking and the other hesitating and finally answering without confidence could not easily be grasped in an interview, mainly because actors would be embarrassed to recognize their lack of proficiency and competence in the topics being discussed in the meeting. The recurrence of such dynamics is key to the emergence of "authoritative" metaphors, and such a recurrence can feasibly be grasped with our approach.

\section{The implications of theorizing practice by temporally bracketing discourses}

The foremost consequence of the temporally-bracketing-discourse strategy is that it leads the researcher to a deep understanding of discursive practices through their investigation of micro-interactions over time, without losing the broad context. First, in adopting this approach that privileges the combination of different data collection techniques, we were in a better position to understand the structuration process as it evolved. Although actions and discourse - the "manifestation" of language structures and linguistic processes that brings things into existence - strongly influence each other, they cannot be analyzed in isolation. Viewed separately, actions and discourses convey partial accounts of reality construction. Put differently, organizational actors do not talk about everything they do, do not do everything they talk about, and sometimes say one thing but do the opposite. By focusing on texts-in-action, we examined texts as they were being produced and disseminated within an interaction. In particular, the use of interviews in tandem with sustained observations allowed us to go beyond the explicit content of interviews and to take into account the tacit or unspoken elements in the discourse. This analytical approach was fundamental for conceiving the image of "being blind", when clients were unsure of the decisions they were taking and the potential future impacts of these decisions on the project, but were afraid of showing their fragility by admitting their lack of understanding of the technology. Such analysis could have focused too much on the official discourse of the actors involved, thereby missing the opportunity to capture how social practices are structured in interactions.

Second, our approach facilitates analysis of the duality of structure in discursive practices that create or maintain certain patterns of resource mobilization and decision power that translate the broader patterns of social interaction. In the case we illustrated here, using a fine-grained approach to temporal bracketing we were able to capture the sustained mobilization of texts-in-action over time, which highlighted a consultant's previous experience and accumulated knowledge through the use of technical jargon and language, thereby legitimizing the consultant's role as an authoritative agent. We could observe, for instance, the consultants' efforts to legitimize their roles as experts in different phases in the project, when they concealed ambiguities with rational arguments about "tested" methodologies and implementation agendas (which are supposed to allow "accurate" information to be elicited about user context) and proven best practices (which are supposed to supplant "old" user practices). If this analysis had adopted a cross-sectional approach instead, we would have lost the opportunity to see how power inequality was constructed through the consolidation of these discursive practices over time. 


\section{CONCLUDING REMARKS}

In this paper we engage with work at the crossroads of structuration theory and discursive analysis to propose a methodological tool for practice-based studies. We develop and describe the application of the temporal bracketing of discourses, a theorizing approach supporting researchers in "zooming-in and out", but also "over-time", in practices (Berthod et al., 2017). The approach prescribes the observation of the production and consumption of texts-in-action over time. These texts are bracketed into successive periods in order to examine how they have cumulatively contributed to the structuring of the authoritative discursive practices that shape subsequent doings and sayings. The combination of bracketing with the framework proposed by Fairclough reminds researchers that explanation of the production and reproduction of social practices depends on their connection to each other and to broader political, cultural and social contexts.

Our article contributes to organizational and management studies in two ways. First, in working "at the crossroads", our article responds to recurrent calls to find better ways to establish the connections between localized interactions and broader contexts (Nicolini, 2009; Seidl \& Whittington, 2014). We reiterate the potential of adopting a dual perspective, in that it affords the opportunity to make sharper connections between localized texts-in-action and broader social structures across time. It prevents practice-based scholars from restricting their analysis to the organizational level and encourages them to go further, shedding light on the recursive relationship between texts-in-action, organizational practices and broader social structures.

Second, we propose temporally bracketing discourses as a theorizing approach that is useful for practiceoriented researchers who are committed to engaging with the field in real time and over time. This approach highly values deep involvement in the field, from data collection in real time and over time to a context-sensitive analysis, which is consistent with a practice perspective (Feldman \& Orlikowski, 2011; Jarzabkowski et al., 2007). Intense engagement with the field over a considerable amount of time might allow researchers to appreciate how texts-in-action progressively shaped and consolidated discursive practices that were coherent and connected to a broad context, thus helping them understand how such recursiveness represents, in fact, not only recursiveness but the vigorously pursued notion of duality.

Our work is not the first to combine structuration theory and discourse analysis, as other authors have already worked at these crossroads. We are probably the first to focus on a detailed methodological tool, combining, as promised, the local/broad connections allowed at the crossroads. We end by proposing a research agenda for future studies, organized along three main avenues. First, scholars might further problematize the connections between theoretical bridges and methodological approaches, by nurturing existing debates of theory and method as being interdependent and exploring the implications of new methodological tools for theorizing. Second, the key role of temporality should be revisited using practice-based theories. It has been pointed out that temporality is an often-neglected dimension in organization studies more generally (Leitch \& Palmer, 2010), and in discursive studies in particular (Heracleous, 2013). We certainly believe that a deeper engagement with temporality will be helpful. Third, as suggested by Feldman and Orlikowski (2011), a commitment to a practice lens requires deep engagement in the field - observing, collecting and analyzing empirical material in real time and over time. This is in line with the ascendant valuing of ethnographical techniques in management research (Berthod et al., 2017; Cunliffe, 2011). Future studies might assess the appropriateness of other research strategies in using the proposed methodological tool, particularly those based on participatory inquiry (Reason \& Bradbury, 2008), a powerful but as yet underexplored methodological strategy in organization studies. 
Working in 'transition zones' is both risky and promising. We argue that our proposal takes a further step in proposing an analytical tactic that supports 'conjunctive-style theorizing'. As stated by Tsoukas (2017), complex theorizing is purposefully conjunctive and privileges: “(a) the discursive, materially-mediated practices into which agents are thrown, as well as the intrinsic capacity of agents to take a stand for what they experience, and work out possible ways to be; (b) the situational uniqueness that is characteristic of all practical action; and (c) the unfolding nature of organizational reality" (p. 148). By proposing a methodological tool that stands at the crossroads of Giddens' structuration theory and Fairclough's critical discourse analysis, we contribute to contemporary debates in organization studies.

\section{REFERENCES}

Balogun, J., Jarzabkowski, P., \& Vaara, E. (2011). Selling, resistance and reconciliation: A critical discursive approach to subsidiary role evolution in MNEs. Journal of International Business Studies, 42(6), 765-786. doi: 10.1057/jibs.2011.13

Barley, S. R. (1986). Technology as an occasion for structuring: Evidence from observation of CT scanners and the social order of radiology departments. Administrative Science Quarterly, 31,78-108. doi:10.2307/2392767

Berthod, O., Grothe-Hammer, M., \& Sydow, J. (2017). Network ethnography: A mixed-method approach for the study of practices in interorganizational settings. Organizational Research Methods, 20(2), 299-323. doi:10.1177/1094428116633872

Bourdieu, P. (1990). The logic of practice. Stanford, CA: Stanford university press.

Carter, C., Clegg, S. R., \& Kornberger, M. (2008). Strategy as practice? Strategic Organization, 6(1), 83-99. doi: $10.1177 / 1476127007087154 \mathrm{~V}$

Cassell, C., \& Bishop, V. (2019). Qualitative data analysis: Exploring themes, metaphors and stories. European Management Review, 16(1), 195-207. doi: 10.1111/emre.12176

Chouliaraki, L., \& Fairclough, N. (2010). Critical discourse analysis in organizational studies: Towards an integrationist methodology. Journal of Management Studies, 47, 1213-1218. doi: 10.1111/j.1467-6486.2009.00883.x

Cohen, I. J. (1989). Structuration theory: Anthony Giddens and the constitution of social life. New York, USA: St. Martin's Press.

Cornelissen, J.P., Oswick, C., Christensen, L.T., \& Phillips, N.(2008). Metaphor in organizational research: Context, modalities and implications for research - introduction. Organization Studies, 29(1), 7-22. doi: 10.1177/0170840607086634

Cunliffe, A. L. (2011). Crafting qualitative research: Morgan and Smircich 30 years on. Organizational Research Methods, 14(4), 647-673. doi: 10.1177/1094428110373658

Denis, J. L., Langley, A., \& Rouleau, L. (2007). Strategizing in pluralistic contexts: Rethinking theoretical frames. Human Relations, 60(1),179-215. doi: 10.1177/0018726707075288
Fairclough, N. (1992). Discourse and social change. Cambridge, UK: Polity Press.

Fairclough, N. (1995). Critical discourse analysis: The critical study of language. London, UK: Longman.

Fairclough, N., \& Wodak, R. (1997). Critical discourse analysis. In T. A. Van Dijk (Ed.), Discourse studies: A multidisciplinary introduction (Vol. 2, pp. 258-284). London, UK: Sage.

Feldman, M. S. (2004). Resources in emerging structures and processes of change. Organization Science, 15(3), 295-309. doi: 10.1287 /orsc. 1040.0073

Feldman, M. S., \& Orlikowski, W. J. (2011). Theorizing practice and practicing theory. Organization Science, 22(5), 1240-1253. doi: $10.1287 /$ orsc. 1100.0612

Foucault, M. (1980). Power/knowledge: Selected interviews and other writings, 1972-1977. New York, US: Pantheon Books.

Giddens, A. (1976). New rules of sociological method. New York, USA: Basic Books.

Giddens, A. (1984). The constitution of society. Berkeley, USA: University of California Press.

Giddens, A. (1989). A reply to my critics. In D. Held \& J. B Thompson (Eds.), Social theory of modern societies: Anthony Giddens and his critics (pp. 249-301). Cambridge, UK: Cambridge University Press.

Giddens, A., \& Pierson, C. (1998). Conversations with Anthony Giddens: Making sense of modernity. Cambridge, UK: Polity Press.

Gioia, D., \& Pitre, E. (1990) Multiparadigm perspectives on theory building. Academy of Management Review, 15(4), 584596. doi: $10.5465 /$ amr.1990.4310758

Grant, D., Hardy, C., Oswick, C., \& Putnam, L. L. (2004) Introduction: Organizational discourse: Exploring the field. In D. Grant, C. Hardy, C. Oswick, \& L. L. Putnam (Eds.), The SAGE handbook of organizational discourse (pp. 1-36). London, UK: Sage Publications.

Grant, D., Keenoy, T., \& Oswick, C. (2001). Organizational discourse: Key contributions and challenges. International Studies of Management and Organization, 31(3), 5-24. doi: 10.1080/00208825.2001.11656818 
Hardy, C. (2001). Researching organizational discourse. International Studies of Management and Organization, 31(3) 25-47.doi: 10.1080/00208825.2001.11656819

Held, D., \& Thompson, J. B. (1989). Social theory of modern societies: Anthony Giddens and his critics. Cambridge, UK: Cambridge University Press.

Heracleous, L. (2006). A tale of three discourses: The dominant, the strategic and the marginalized. Journal of Management Studies, 43(5),1059-1087. doi: 10.1111/j.14676486.2006.00629.x

Heracleous, L. (2013). The employment of structuration theory in organizational discourse: Exploring methodological challenges. Management Communication Quarterly, 20(10),18. doi: $10.1177 / 0893318913504498$

Heracleous, L., \& Barrett, M. (2001). Organizational change as discourse: Communicative actions and deep structures in the context of information technology. Academy of Management Journal, 44, 755 778. doi: 10.5465/3069414V

Heracleous, L., \& Jacobs, C. D. (2008). Understanding organizations through embodied metaphors. Organization Studies, 29(1), 45-78. doi: 10.1177/0170840607086637

Howard-Grenville, J. A. (2005). The persistence of flexible organizational routines: The role of agency and organizational context. Organization Science, 16(6), 618-636. doi: 10.1287/ orsc.1050.0150

Jarzabkowski, P. (2004). Strategy as practice: Recursiveness, adaptation, and practices-in-use. Organization Studies, 25, 529-560. doi: 10.1177/0170840604040675

Jarzabkowski, P. (2008). Shaping strategy as a structuration process. Academy of Management Journal, 51, 621-650. doi: 10.5465/amr.2008.33664922

Jarzabkowski, P., Balogun, J., \& Seidl, D. (2007). Strategizing: The challenges of a practice perspective. Human Relations, 60(1), 5-27. doi: $10.1177 / 0018726707075703$

Jarzabkowski, P., Bednarek, R., \& Lê, J. K. (2014). Producing persuasive findings: Demystifying ethnographic textwork in strategy and organization research. Strategic Organization, 12(4), 274-287. doi: 10.1177/1476127014554575

Kouamé, S., \& Langley, A. (2018). Relating microprocesses to macro-outcomes in qualitative strategy process and practice research. Strategic Management Journal, 39(3), 559-581. doi: $10.1002 / \mathrm{smj} .2726$

Kuhn, T. R., \& Putnam, L. L. (2014). Discourse and communication. In P. S. Adler, P. Du Gay, G. Morgan, \& M. Reed (Eds.), Oxford handbook of sociology, social theory and organization studies: Contemporary Currents (pp. 414-430). Oxford, UK: Oxford Handbooks.

Lacerda, D. S., \& Brulon, V. (2013). Política das UPPs e espaços organizacionais precários: Uma análise de discurso. RAE Revista de Administração de Empresas, 53(2), 130-141. doi: 10.1590/So034-75902013000200002

Langley, A. (1999). Strategies for theorizing from process data. Academy of Management Review, 24, 691-710. doi: 10.5465/ amr.1999.2553248
Lavarda, R. A. B., Canet-Giner, M., \& Peris-Bonet, F. (2010). How middle managers contribute to strategy formation process: Connection of strategy processes and strategy. RAE-Revista de Administração de Empresas, 50(4), 358-370. doi:10.1590/ So034-75902010000400002

Leitch, S., \& Palmer, I. (2010). Analysing texts in context: Current practices and new protocols for critical discourse analysis in organization studies. Journal of Management Studies, 47, 1194-1212. doi: 10.1111/j.1467-6486.2009.00884.x

Murtagh, L. (2007). Implementing a critically quasi-ethnographic approach. The Qualitative Report, 12(2), 193-215

Nicolini, D. (2009). Zooming in and out: Studying practices by switching theoretical lenses and trailing connections. Organization Studies, 30(12), 1391-1418. doi: $10.1177 / 0170840609349875$

Novak, L., Brooks, J., Gadd, C., Anders, S., \& Lorenzi, N. (2012). Mediating the intersections of organizational routines during the introduction of a health IT system. European Journal of Information Systems, 21(5), 552-569. doi: 10.1057/ejis.2012.2

Orlikowski, W. J. (2000). Using technology and constituting structures: A practice lens for studying technology in organizations. Organization Science, 11, 404-428. doi: 10.1287/orsc.11.4.404.14600

Phillips, N., \& Hardy, C. (2002). Discourse analysis: Investigating processes of social construction. Cambridge, UK: Sage Publications.

Phillips, N., \& Oswick, C. (2012). Organizational discourse: Domains, debates, and directions. The Academy of Management Annals, 6(1),435-481. doi: 10.5465/19416520.2012.681558

Pozzebon, M. (2004). The influence of a structurationist view on strategic management research. Journal of Management Studies, 41(2), 247-272. doi: j.1467-6486.2004.00431.x

Pozzebon, M., \& Pinsonneault, A. (2005). Challenges in conducting empirical work using structuration theory: Learning from IT research. Organization studies, 26(9), 1353 1376. doi: $10.1177 / 0170840605054621$

Reason, P., \& Bradbury, H. (2008). The Sage handbook of action research: Participative inquiry and practice. London, UK: Sage Publications

Rodríguez, C., \& Pozzebon, M. (2010). The implementation evaluation of primary care groups of practice: a focus on organizational identity. BMC Family Practice, 11(1), 1-10. doi: 10.1186/1471-2296-11-15

Schatzki, T. R. (1996). Social practices: A Wittgensteinian approach to human activity and the social. Cambridge, UK: Cambridge University Press.

Seidl, D., \& Whittington, R. (2014). Enlarging the strategyas-practice research agenda: Towards taller and flatter ontologies. Organization Studies, 35(10), 1407-1421. doi: $10.1177 / 0170840614541886$

Spee, A. P., \& Jarzabkowski, P. (2011). Strategic planning as communicative process. Organization Studies, 32(9), 12171245. doi: $10.1177 / 0170840611411387$ 
Taylor, J. R., Cooren, F., Giroux, N., \& Robichaud, D. (1996). The communicational basis of organization: Between the conversation and the text. Communication Theory, 6(1), 1-39. doi: 10.1111/j.1468-2885.1996.tboo118.x

Thompson, M. (2004). ICT, power, and developmental discourse: A critical analysis. The Electronic Journal on Information Systems in Developing Countries, 20(4), 1-25. doi: 10.1007/978-0-387-35634-1_17

Titscher, S., Meyer, M., Wodak, R., \& Vetter, E. (2000). Methods of text and discourse analysis. London, UK: Sage Publications

Tsoukas, H. (2017). Don't simplify, complexify: From disjunctive to conjunctive theorizing in organization and management studies. Journal of Management Studies, 54(2), 132-153. doi: 10.1111/joms.12219

Whittington, R. (2006). Completing the practice turn in strategy research. Organization Studies, 27, 613-634. doi: 10.1177/0170840606064101

Whittington, R. (2010). Giddens, structuration theory and strategy as practice. In D. Golsorkhi, L. Rouleau, D. Seidl, \& E. Vaara (Eds.), Cambridge handbook of strategy as practice ( $\mathrm{pp}$. 109-126). Cambridge, UK: Cambridge University Press

Wood, L. A., \& Kroger, R. O. (2000). Doing discourse analysis: Methods for studying action in talk and text. London, UK: Sage Publications

\section{AUTHORS' CONTRIBUTIONS}

The authors declare that they participated in all stages of development of the manuscript. The first version was developed by Pozzebon and Rodrigues. Delgado worked intensively in the more recent versions. All authors worked on the conceptualization and theoretical-methodological approach. The three authors participated to the theoretical review. Data collection and analysis were coordinated by Pozzebon. All authors worked together in the writing and final revision of the manuscript. 